計 測 自 動制 御 学 会論文 集

Vol.40, No.7, 770/776 (2004)

\title{
スライディングモード制御による電子制御 スロットルシステムの位置制御
}

\author{
ウメルジャン サウット*・樋 口＼cjkstart幸＼cjkstart治** \\ 中 野 和 司**. 松 尾 孝 美***
}

\begin{abstract}
Position Control of Electronic Throttle Chamber Using Sliding-Mode
Controller with Prescribed Transient Response
\end{abstract}

Sawut Umerujan*, Kohji HiguChi**,

Kazushi NAKANO** and Takami MATSUO ${ }^{* * *}$

\begin{abstract}
With increasing demand for high fuel efficiency, better exhaust control measures, comfort and high performance on current vehicles, electronic control of the throttle chamber which decides the engine output, is getting advanced day by day. It is expected that this trend will be maintained towards electronic control of the throttle chamber in conjunction with injection air-amount control, drive control, traction control, etc. A control methód for electronic throttle servo system is proposed, which consists of a DC motor, a throttle valve and a return spring. The control method fulfills the demand for high robustness in nonlinear opening of the throttle. In this paper, a sliding-mode controller with prescribed transient response is designed for electronic throttle chamber systems. By using a function augmented sliding hyperplane, it is guaranteed that the output tracking error converges to zero in a finite time. Simulation and experimental results are shown for the confirmation of effectiveness of the sliding-mode controller with prescribed transient response.
\end{abstract}

Key Words: throttle chamber, VSS observer, function augmented sliding-mode control

\section{1.はじめに}

自動車エンジンの発展の原動力になった燃費改善, 排気ガ ス対策については，国内規制の対応に目処がつき，エンジン 系の制御は動力性能と快適性の追求にシフトした。その後, いっそうの低燃費, 排気ガス浄化, 快適性などの向上を求め て，エンジン系と駆動系をトータルに制御する方向に進展 してきている。このように制御への要求仕様が多様化・高度 化していく中で, エンジンの目標出力を決定するスロットル チャンバの電子制御化も急速に進んでおり, 今後もさらにそ の傾向は続くものと思われる。このスロットルチャンバの電 子制御技術により，直噴エンジンの空気量制御，アイドル空 気量制御, トラクションコントロール制御などの機能を取

\footnotetext{
* (株) ニッキ 厚木市上依知 3029

** 電気通信大学 調布市調布ヶ丘 1-5-1

*** 大分大学 大分市旦野原 700

* NIKKI Co.,Ltd., 3029 Kamiechi, Atsugi

** The University of Electro-Communications, 1-5-1 Chofu-ga-oka, Chofu

*** Oita University, 700 Dannoharu, Oita

(Received November 10, 2003)

(Revised April 13, 2004)
}

り込み，高精度な統合システムを構築することが可能とな $3^{1)-3)}$.

本論文では, DC モータ, バタフライ弁, リターンスプリ ングから構成された，スロットル角度に高いロバスト性が 要求される電子制御スロットルサーボ系に対するモデリン グおよびロバストスライディングモード制御を用いた場合 の設計法について述べる。まず，通常のスロットル角度だけ 用いた通常のフィードバック制御では性能が不十分であるた め, 非線形 VSS (Variable Structure System) オブザーバ を用いたスライディングモード制御系を提案する。この制 御系はファンクションオーグメントスライディング切換超平 面 ${ }^{4), 5)}$ を用いるもので，これにより出力軌道誤差を有限時 間で 0 に収束させることができる，さらに，制御対象のパ ラメータによってスライディングモードを生じるとき制御入 カおよびスロットル角度にチャタリングが発生したり，ノイ ズによる振動が無視できなくなる場合がある。この問題を解 決するために飽和関数を用いたスライディングモード制御器 の設計法についても述べる. 最後に, 提案手法の有効性をシ ミュレーションおよび実機による実験によって実証する。 


\section{2. 電子制御スロットルシステムの数式のモデル}

制御をうまく行なうためには，制御対象の特性をいかによ く知るかということが大切である。制御対象の基本的な構 造しかわかっていないと, 望ましい制御結果を得ることは困 難である．本研究では，Fig.1に示すような電子制御スロッ トルシステムを制御対象とし，その数式モデルを以下のよう に求める ${ }^{6)-8)}$.

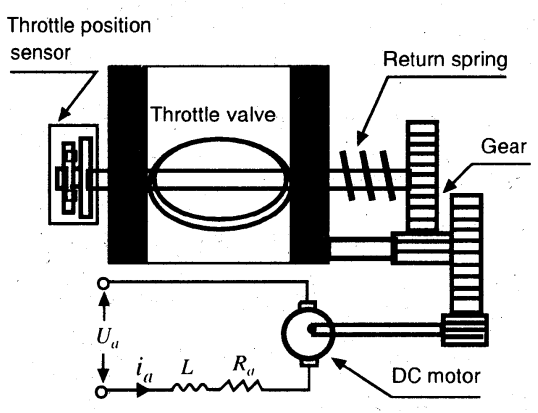

Fig. 1 Electronic throttle chamber system

電機子における電流と電圧の関係は次式で表わされる.

$$
L \frac{d i_{a}}{d t}+R_{a} i_{a}+K_{e} N \frac{d \theta}{d t}=U_{a}
$$

ここに, $i_{a}$ は電機子電流, $U_{a}$ は電機子両端の入力電圧, $L$ と $R_{a}$ は電機子のインダクタンスと抵抗, $K_{e}$ は誘起電圧定 数, $N$ はギヤ比で, $\theta$ はスロットル角度である。一方, 電機 子に加わる電磁的なトルクを $T=K_{t} i_{a}$ とすれば，電子制 御スロットルシステムの動特性は次式のように表わされる。

$$
J \frac{d^{2} \theta}{d t^{2}}+D \frac{d \theta}{d t}+d_{k} \operatorname{sgn}\left(\frac{d \theta}{d t}\right)+K_{s} \theta=N K_{t} i_{a}
$$

ここに，Jは系のスロットル軸換算での全慣性モーメント, $D$ は粘性摩擦係数, $d_{k}$ はクーロン摩擦で, $K_{s}$ はリターン スプリングのばね定数である. 電機子のインダクタンス成分 $L$ は無視できるとして，(1) 式を (2) 式に代入すると次式を 得る.

$$
\begin{aligned}
\ddot{\theta} & =-\frac{1}{J}\left(D+\frac{N^{2} K_{t} K_{e}}{R_{a}}\right) \dot{\theta} \\
& -\frac{1}{J} d_{k} \operatorname{sgn}(\dot{\theta})-\frac{1}{J} K_{s} \theta+\frac{N K_{t}}{R_{a} J} U_{a}
\end{aligned}
$$

(3) 式において状態变数を $x_{1}=\theta, x_{2}=\dot{\theta}$ とおけばシステ 么の状態方程式と出力方程式はつぎのように求められる.

$$
\begin{aligned}
{\left[\begin{array}{c}
\dot{x_{1}} \\
\dot{x_{2}}
\end{array}\right] } & =\left[\begin{array}{c}
x_{2} \\
a_{1} x_{1}+a_{2} \operatorname{sgn}\left(x_{2}\right)+a_{3} x_{2}
\end{array}\right] \\
+ & {\left[\begin{array}{c}
b_{1} \\
b_{2}
\end{array}\right] U_{a} }
\end{aligned}
$$

$y=x_{1}$

上の (4) 式では

$$
a_{1}=-\frac{K_{s}}{J}
$$

$$
\begin{aligned}
& a_{2}=-\frac{d_{k}}{J} \\
& a_{3}=-\left(\frac{D}{J}+\frac{N^{2} K_{t} K_{e}}{R_{a} J}\right) \\
& b_{1}=0 \\
& b_{2}=\frac{N K_{t}}{R_{a} J}
\end{aligned}
$$

であり，(5) 式の $y$ は観測值である。

\section{3. 制御系の設計}

\section{1 非線形 VSS オブザーバの設計}

ここでは，(5) 式のようにシステムの状態のうちスロット ル角度しか測定できないとする。このようなスロットル角度 のみのフィードバックでは制御性能において不十分であるた め，ここですべての状態量を推定する機能をもつ状態オブ ザーバを設計する。まず，(4) 式と (5) 式を次式のように書 き直す.

$$
\begin{aligned}
\dot{\boldsymbol{x}} & =f(\boldsymbol{x})+\boldsymbol{b} U_{a} \\
y & =\boldsymbol{c}^{T} \boldsymbol{x}
\end{aligned}
$$

ここで，状態ベクトル $\boldsymbol{x}$ をつぎのように定義する.

$$
\boldsymbol{x}=\left[\begin{array}{ll}
x_{1} & x_{2}
\end{array}\right]^{T}
$$

また，

$$
f(\boldsymbol{x})=\left[\begin{array}{c}
x_{2} \\
a_{1} x_{1}+a_{2} \operatorname{sgn}\left(x_{2}\right)+a_{3} x_{2}
\end{array}\right]
$$

であり, $\boldsymbol{b}=\left[\begin{array}{ll}0 & b_{2}\end{array}\right]^{T}, \boldsymbol{c}=\left[\begin{array}{ll}1 & 0\end{array}\right]^{T}$ である.

この非線形系に対して，下記のようなシステムの全状態量 を推定するロバストVSS オブザーバを設計する9),10).

$$
\begin{aligned}
& \dot{\hat{\boldsymbol{x}}}=f(\hat{\boldsymbol{x}})+\boldsymbol{b} U_{a}+\boldsymbol{b} \zeta \operatorname{sgn}(\bar{y})+\boldsymbol{k} \bar{y} \\
& \bar{y}=\hat{y}-y=\boldsymbol{c}^{T}(\hat{\boldsymbol{x}}-\boldsymbol{x})
\end{aligned}
$$

ここで

$$
\operatorname{sgn}(\bar{y})=\left\{\begin{array}{rll}
1 & \text { if } & \bar{y}>0 \\
0 & \text { if } & \bar{y}=0 \\
-1 & \text { if } & \bar{y}<0
\end{array}\right.
$$

であり, $\hat{\boldsymbol{x}}$ はシステム状態の推定值を表わし, $\boldsymbol{k}=\left[\begin{array}{ll}k_{1} & k_{2}\end{array}\right]^{T}$ はオブザーバゲイン行列, $\boldsymbol{b} \operatorname{sgn}(\bar{y})$ はオブザーバの非線形 補償入力項, $\zeta$ はスカラゲインである. 推定誤差を

$$
e_{r}=\hat{x}-\boldsymbol{x}
$$

とおくと，誤差システムはつぎのようになる。

$$
\begin{aligned}
\dot{\boldsymbol{e}_{\boldsymbol{r}}} & =f(\hat{\boldsymbol{x}})-f(\boldsymbol{x})+\boldsymbol{k} \boldsymbol{c}^{T} \boldsymbol{e}_{\boldsymbol{r}} \\
& +\boldsymbol{b} \boldsymbol{c}^{T} \zeta \operatorname{sgn}\left(\boldsymbol{e}_{\boldsymbol{r}}\right)
\end{aligned}
$$

上式のオブザーバゲイン $\boldsymbol{k}$ は，(14) 式が安定となるように

$$
J_{i}=\int_{0}^{T_{i}} \bar{y}^{2}(t) d t
$$

を最小にするように遺伝的アルゴリズム $(\mathrm{GA})$ を用いて決 定することができる（詳細については参考文献 6) を参照さ れたい). 


\section{2 スライディングモード制御系の設計}

従来の PID 制御では目標值やシステムパラメータ（電圧 や負圧）などが変化した場合は，同じ制御パラメータで制御 が困難であるため P， I，Dの各ゲインも同時に変化させな ければならないなどの欠点がある。この問題に対して PID 制御の代わりにロバストスライディングモード制御を提案 する.

スライディングモード制御のロバスト性は，最もきわだっ た特性の一つである。線形または非線形の高次微分方程式 で表わされたプラントに対して，スライディングモード超平 面の微分方程式はシステムのモデル化誤差と不可観測な外 生入力による影響を完全になくすことができるものである。 このようにスライディングモードはシステムのモデル化誤 差や外乱などに対してロバストというより不変であるとい えよう.よって, スライデイングモード制御は, 線形系はも ちろん非線形系, パラメー夕変動系, 時変系など, 未知パラ メータや未知外乱を有する系に容易に適用でき，後述するよ うに希望の特性を切換面として設計すれば，システムの状態 は所望の特性に拘束され適応していくことになる。この結 果，スライデイングモード制御は，制御入力が不連続的に変 化する非線形制御と，スライディングモードが存在すればそ れにそって適応していく適応制御の両面をもっていることに なる．制御の目的は，切換面上にない状態を切換面に収束さ せ，その面上に保つことである。.なお切換超平面の設計は基 本的には線形制御理論のすべてを適用できる ${ }^{11), 12) . ~}$

状態ベクトルはオブザーバによる推定值を用いることにし， (6) 式の非線形系に対するファンクションオーグメントスラ イディング切換超平面 $s(t)$ として, 次式を定義する ${ }^{4), 5)}$.

$$
s(t)=s_{1} e(t)+s_{2} \dot{e}(t)-z(t)
$$

ここに, $e(t)=x_{1}(t)-x_{d}(t)$ であり, $x_{d}(t)$ は 2 回連 続微分可能な規範軌道 (目標出力) , $s_{1}, s_{2}$ は正定数, $z(t)=s_{1} q(t)+s_{2} \dot{q}(t), q(t)$ は増大関数である. $q(t)$ は ある境界区間 $\left[0, t_{f}\right], t_{f}>0$ によって設計する。また， $q(t)$, $\dot{q}(t)$ に対して初期条件をそれぞれ $q(0)=e(0), \dot{q}(0)=\dot{e}(0)$ と定義すると，この条件より明らかにシステムの状態が最初 の瞬間にスライディング切換超平面上にあることがわかる。 すなわち， $s(0)=0$ である.したがって，提案されたスラ イディング切換超平面 (16) 式を用いることによって，スラ イディングモードの存在に対してつぎの結論が得られる。も し，スライディングモード制御入力

$$
\begin{aligned}
U_{a} & =K_{p}\left[-s_{1} \dot{e}+s_{2}\left(\ddot{x}_{d}-a_{1} x_{1}-a_{2} \operatorname{sgn}\left(x_{2}\right)\right.\right. \\
& \left.\left.-a_{3} x_{2}\right)+s_{1} \dot{q}+s_{2} \ddot{q}-P \operatorname{sgn}(s)\right]
\end{aligned}
$$

がプラント (4) 式に適用されるなら，このシステムは常 にスライディングモード状態にある。すなわち， $s(t) \equiv 0$ $\forall t>0$ である.ここに

$$
\begin{aligned}
P & =\delta \mid s_{1} \dot{e}-s_{2} \ddot{x}_{d}+s_{2}\left(a_{1} x_{1}+a_{2} \operatorname{sgn}\left(x_{2}\right)\right. \\
& \left.+a_{3} x_{2}\right)-s_{1} \dot{q}-s_{2} \ddot{q} \mid+\eta
\end{aligned}
$$

$$
\operatorname{sgn}(s)=\left\{\begin{array}{rll}
1 & \text { if } & s>0 \\
0 & \text { if } & s=0 \\
-1 & \text { if } & s<0
\end{array}\right.
$$

であり, $\eta>0, K_{p}>0, \delta>0$ である.

切換超平面 $s$ に関するリアプノフ関数の候補を

$$
V=\frac{1}{2} s^{2}
$$

とすると，その時間微分は

$$
\begin{aligned}
\dot{V}= & s \dot{s}=s\left(s_{1} \dot{e}+s_{2} \dot{x}_{2}-s_{2} \ddot{x}_{d}-\dot{z}\right) \\
=s[ & s_{1} \dot{e}-s_{2} \ddot{x}_{2}-\dot{z} \\
& \left.+s_{2}\left(a_{1} x_{1}+a_{2} \operatorname{sgn}\left(x_{2}\right)+a_{3} x_{2}+b_{2} U_{a}\right)\right] \\
= & s\left\{s_{1} \dot{e}-s_{2} \ddot{x}_{2}-\dot{z}\right. \\
& +s_{2}\left(a_{1} x_{1}+a_{2} \operatorname{sgn}\left(x_{2}\right)+a_{3} x_{2}\right) \\
& +\beta\left[-s_{1} \dot{e}+s_{2} \ddot{x}_{d}+\dot{z}-s_{2} a_{1} x_{1}\right. \\
& \left.\left.\quad-s_{2} a_{2} \operatorname{sgn}\left(x_{2}\right)-s_{2} a_{3} x_{2}-P \operatorname{sgn}(s)\right]\right\} \\
= & s\left[( 1 - \beta ) \left(s_{1} \dot{e}-s_{2} \ddot{x}_{d}-\dot{z}+s_{2} a_{1} x_{1}\right.\right. \\
& \left.\left.\left.+s_{2} a_{2} \operatorname{sgn}\left(x_{2}\right)+s_{2} a_{3} x_{2}\right)-\beta P \operatorname{sgn}(s)\right]\right\}(
\end{aligned}
$$

となる.ここに, $\beta=K_{p} s_{2} b_{2}>0$ である. それで，各パラ メー夕の定義より, $\delta>|\beta-1| / \beta$ となるように $\delta$ を決定す れば，(21) 式はつぎのように書き直すことができる。

$$
\begin{aligned}
\dot{V} & =s\left[( 1 - \beta ) \left(s_{1} \dot{e}-s_{2} \ddot{x_{d}}-s_{1} \dot{q}-s_{2} \ddot{q}+s_{2} a_{1} x_{1}\right.\right. \\
& \left.+s_{2} a_{2} \operatorname{sgn}\left(x_{2}\right)+s_{2} a_{3} x_{2}\right)-\beta \delta \mid s_{1} \dot{e}-s_{2} \ddot{x_{d}} \\
& +s_{2} a_{1} x_{1}+s_{2} a_{2} \operatorname{sgn}\left(x_{2}\right)+s_{2} a_{3} x_{2} \\
& \left.-s_{1} \dot{q}-s_{2} \ddot{q} \mid \operatorname{sgn}(s)-\beta \eta \operatorname{sgn}(s)\right]<-\beta \eta|s|
\end{aligned}
$$

したがって， $\dot{V}<0$ となりリアプノフの定理より安定な スライディングモード制御を実現できる。制御パラメータ は，GA を用いてつきの評価関数を最小にするように決定し た. 最終的には, $s_{1}=10.872, s_{2}=0.278, K_{p}=0.142$, $\delta=5.802, \eta=0.325$ となった（詳細については参考文献 6)を参照されたい).

$$
J_{j}=\int_{0}^{T_{j}}|e(t)| d t
$$

なお，Fig.2 は設計した制御系のブロック図である。

\section{4. シミュレーションおよび実験結果}

\section{1 実験条件}

前章で提案した手法の有効性を確認するために，シミュレー ションおよび実機による実験を行なった。シミュレーションお よび実験において, 入出力信号のサンプリング周期 $\Delta t=0.4$ $[\mathrm{ms}], T_{i}=T_{j}=5[\mathrm{~s}]$, 初期状態 $x_{1}(0)=5.0[\mathrm{deg}], x_{2}(0)=$ $0[\mathrm{deg} / \mathrm{s}]$, 目標值 $x_{d}=60.0[\mathrm{deg}], \dot{x}_{d}=0[\mathrm{deg} / \mathrm{s}]$, 目標 値に達するまでの時間 $t_{f}=0.4[\mathrm{~s}]$ とする．ほかの設計パラ メータは Table 1 のとおりである。また，ファンクション オーグメントスライディングモード切換超平面の設計に用い る増大関数 $q(t)$ を次式によって定義する. 


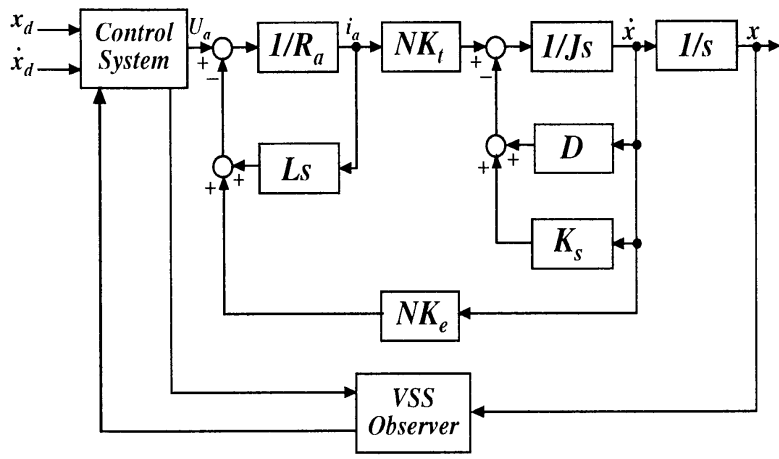

Fig. 2 Block Diagram of Overall Systems

\begin{tabular}{|c|c|}
\hline symbols & values \\
\hline$a_{1}$ & $-1.024 \times 10^{1}$ \\
\hline$a_{2}$ & -0.295 \\
\hline$a_{3}$ & $-7.565 \times 10^{1}$ \\
\hline$b_{2}$ & $5.378 \times 10^{2}$ \\
\hline$k_{1}$ & $-7.065 \times 10^{2}$ \\
\hline$k_{2}$ & 1.028 \\
\hline$\zeta$ & 1.250 \\
\hline
\end{tabular}

$$
q(t)=\left\{\begin{array}{cl}
v_{0}+v_{1} t+v_{2} t^{2}+v_{3} t^{3} & \text { if } 0<t<t_{f} \\
0 & \text { if } t \leq t_{f}
\end{array}\right.
$$

ここに，

$$
\begin{aligned}
& v_{0}=e(0) \\
& v_{1}=\dot{e}(0) \\
& v_{2}=-3 v_{0} / t_{f}^{2}-2 v_{1} / t_{f} \\
& v_{3}=2 v_{0} / t_{f}^{3}+v_{1} / t_{f}^{2}
\end{aligned}
$$

である。これは出力軌道を表わす関数であり，設計者が自由 に定めることができる．たとえば，目標值への収束速度を設 定することもできる(ここでの実験においては，システムの 時定数を考慮し， $t_{f}>0.23[\mathrm{~s}]$ としなければならないことが わかっている).

\section{2 シミュレーション結果および検討}

Fig.3，Fig.4，Fig.5はスロットル角度 $x_{1}$ および角速度 $x_{2}$ ，位相軌道および $\operatorname{sgn}$ 関数を用いた場合の制御入力をそ れぞれ示している。

シミュレーション結果から，スロットル角度は指定された 時間で目標值に収束しているが，過渡応答中にチャタリング 現象により制御入力およびスロットルバルブに高周波振動 が起っていることがわかる。これらは，サンプリング周期を 無限小にすることができないため，現実のスライディング モードは切換面を滑ることにはならず，その近傍でチャタリ ングすることになり，入力の高速切換によって起った現象で ある。ここで，チャタリングを除去するため，通常よく行な われるように sgn 関数の代りにつぎの飽和 (sat) 関数を採用 する。すなわち

$$
\operatorname{sat}(s)=\left\{\begin{array}{lll}
\operatorname{sgn}(s) & \text { if } & |s|>\phi \\
s / \phi & \text { if } & |s| \leq \phi
\end{array}\right.
$$
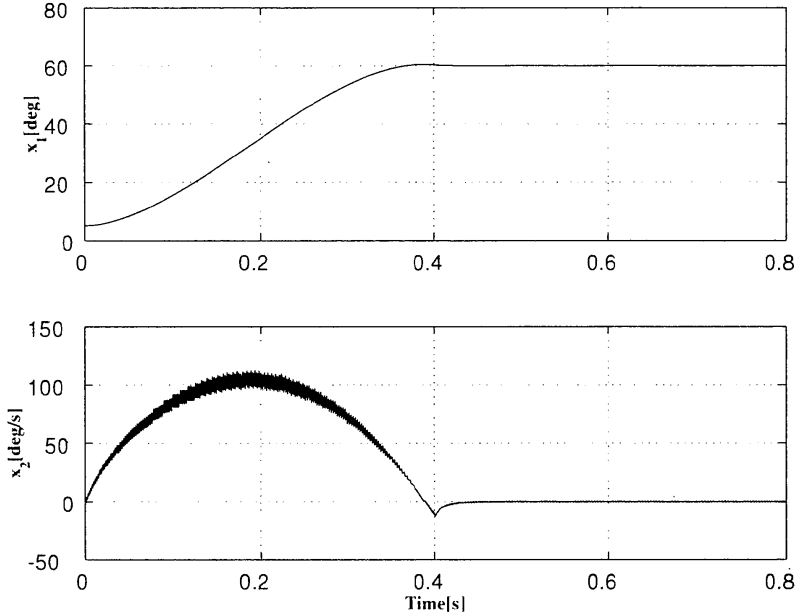

Fig. 3 Simulated throttle angle and angular velocity

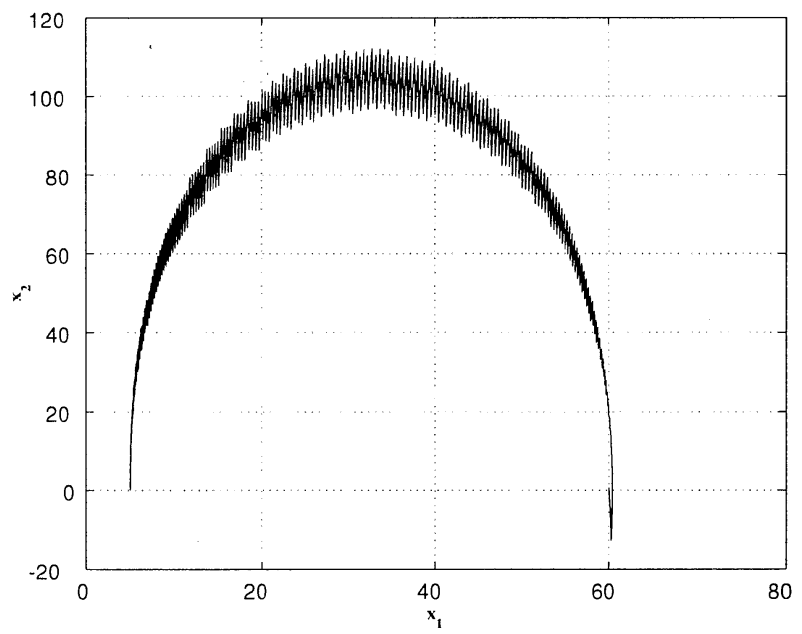

Fig. 4 Simulated phase portrait

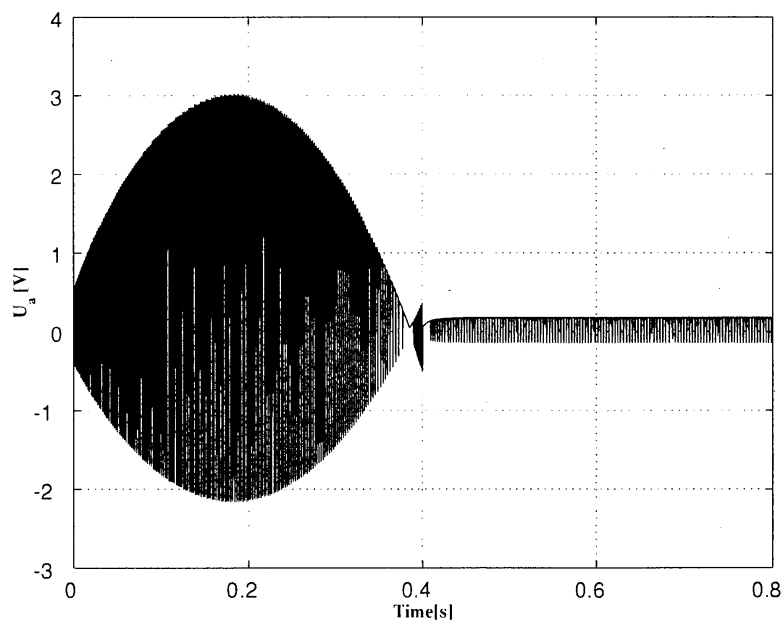

Fig. 5 Simulated control input

とする。ここに， $\phi>0$ はチャタリングを除去するために用 いられる定数である。

Fig.6, Fig.7, Fig.8はスロットル角度 $x_{1}$ および角速度 
$x_{2}$ ，位相軌道および sat 関数を用いた場合の制御入力をそれ ぞれ示している。
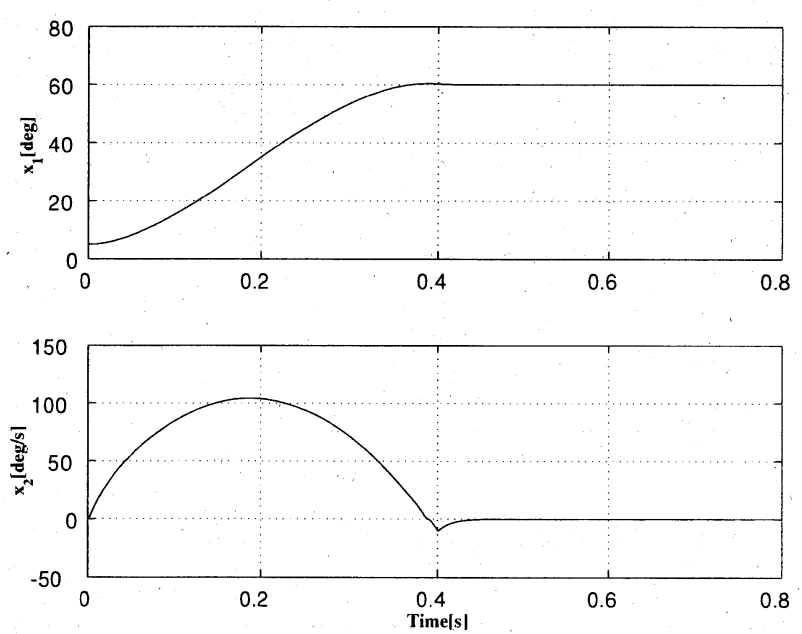

Fig. 6 Simulated throttle angle and angular velocity with sat-function

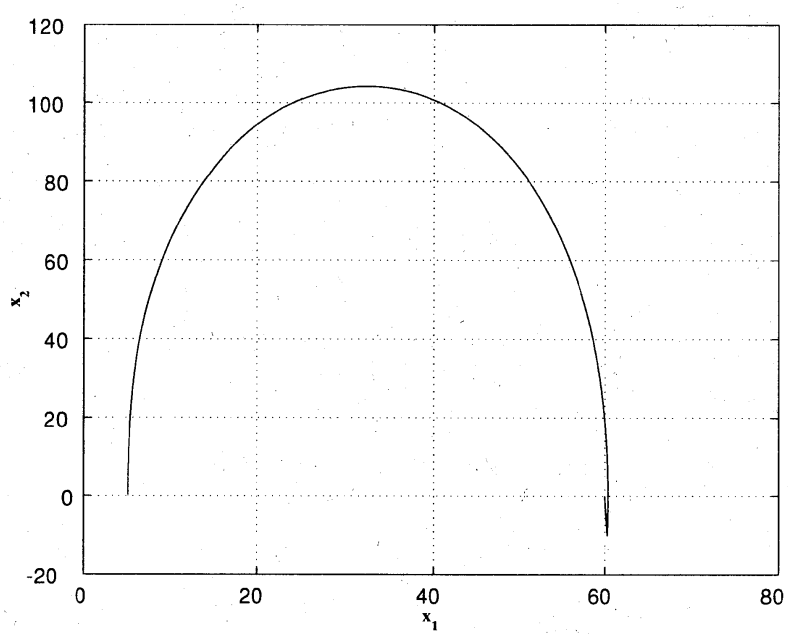

Fig. 7 Simulated phase portrait with sat-function

以上の結果から明らかのように，制御入力およびスロット ル角度ともにチャタリングを起こさず, 指定された時間 $t_{f}$ で目標値に収束して扔り，設計したスライディングモード制 御は安定に動作していることがわかる。

\section{3 実験結果および検討}

Fig.9, Fig.10，Fig.11 は，シミュレーションと同様の 条件で実機による実験を行なった場合のスロットル角度 $x_{1}$ および角速度 $x_{2}$ ，位相軌道および sgn 関数を用いた場合の 制御入力をそれぞれ示している. シミュレーション結果と同 様に，スロットル角度は指定された時間で目標値に収束して いるが, 過渡応答中にチャタリング現象により制御入力お よびスロットルバルブに振動が起っていることがわかる：一 方, Fig.12, Fig.13, Fig.14 はスロットル角度 $x_{1}$ および 角速度 $x_{2}$, 位相軌道および sat 関数を用いた場合の制御入

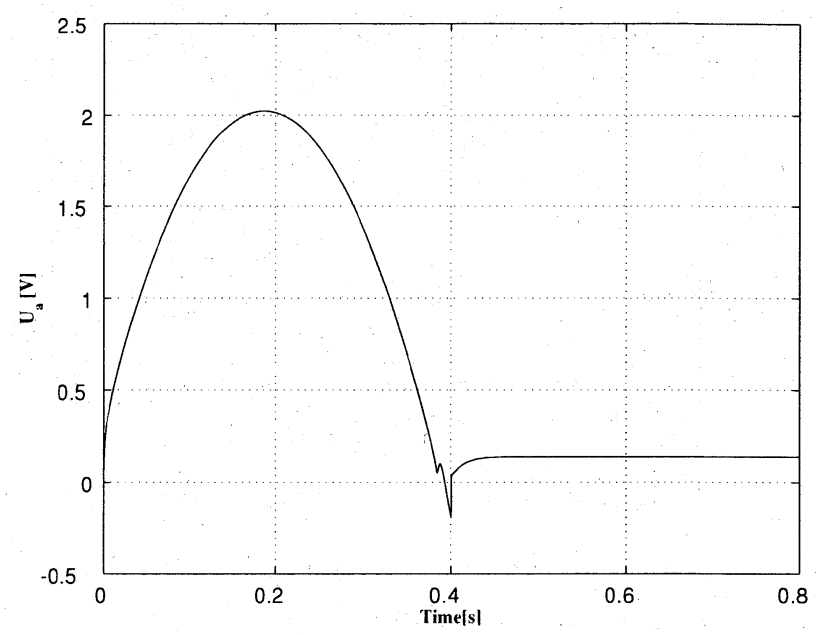

Fig. 8 Simulated control input with sat-function

力をそれぞれ示している. 制御入力およびスロットル角度と もにチャタリングを起こさず, 指定された時間での目標值追 従性能を示している.

これらの実験結果は，シミュレーション結果とほほ一致し ており，提案した手法の有効性が確認できた，さらに，VSS オブザーバおよびスライディングモード制御は安定に動作 することについても確認された。 なお, sgn 関数を用いた場 合の実験結果と sat 関数を用いた場合の実験結果を比較する と，いずれも指定された時間で目標值に収束していることが わかる．特に， sat 関数を用いた場合は，制御入力およびス ロットル角度ともにチャタリングを起こすことなく，良好な 目標值追従性能が得られた。
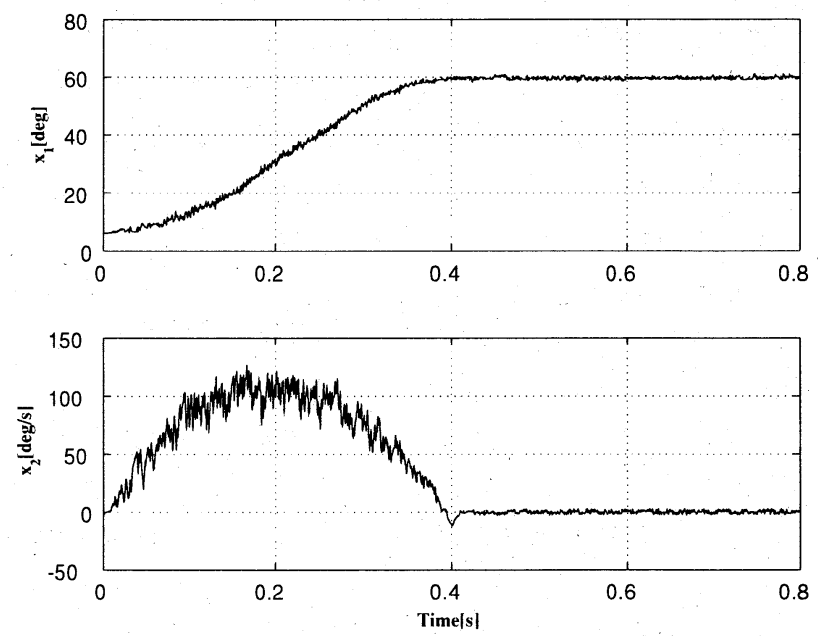

Fig. 9 Experimental throttle angle and angular velocity

\section{5. おわりに}

本研究では電子制御スロットルシステムの位置制御を目 的として, 新たなスライディングモード制御法を提案した. すなわち，ファンクションオーグメントスライディング切換 


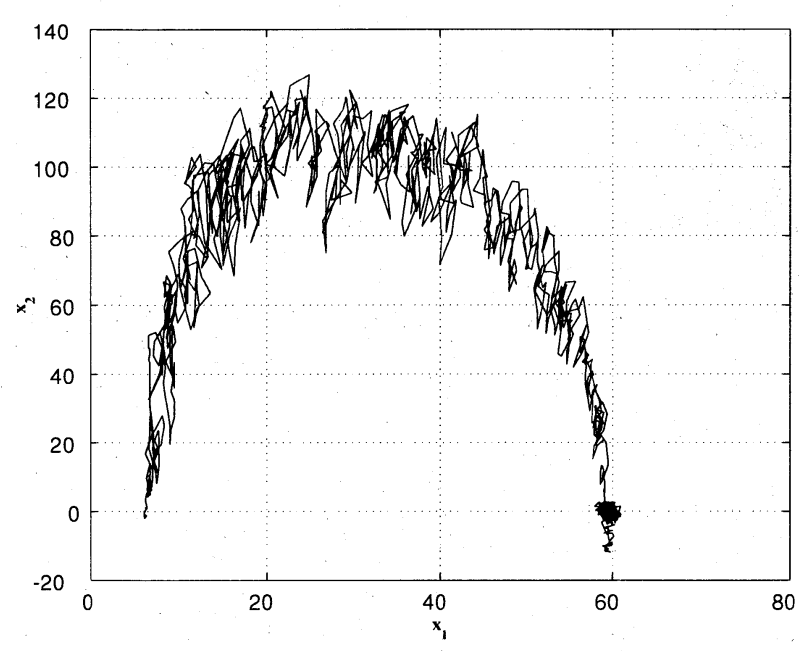

Fig. 10 Experimental phase portrait

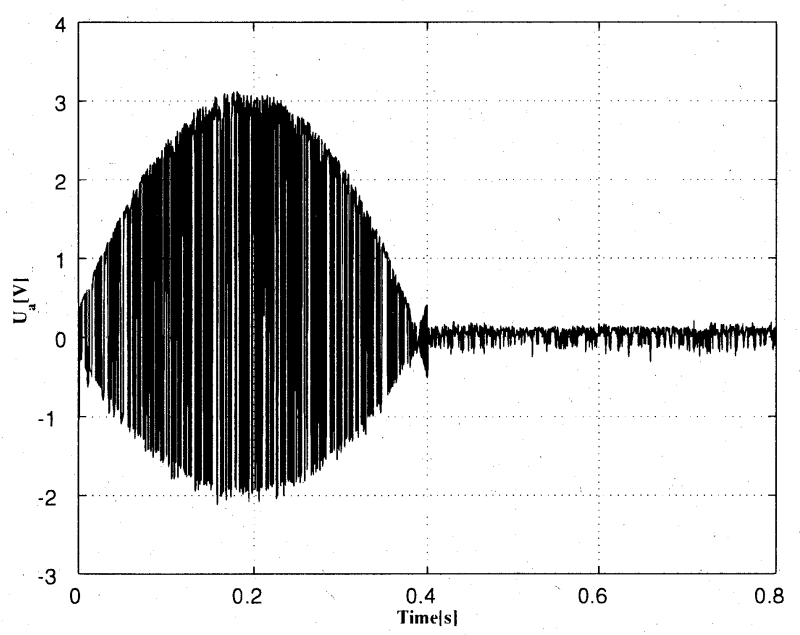

Fig. 11 Experimental control input
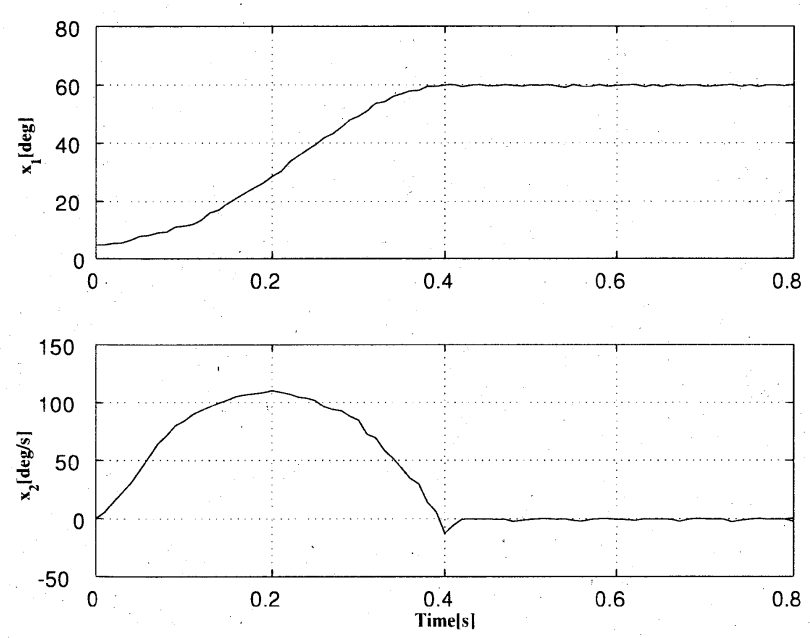

Fig. 12 Experimental throttle angle and angular velocity with sat-function

超平面を用いることにより出力軌道誤差がオーバシュートす ることなく指定された時間で目標值に収束することを可能 にし，シミュレーションおよび実験によって，この手法の有

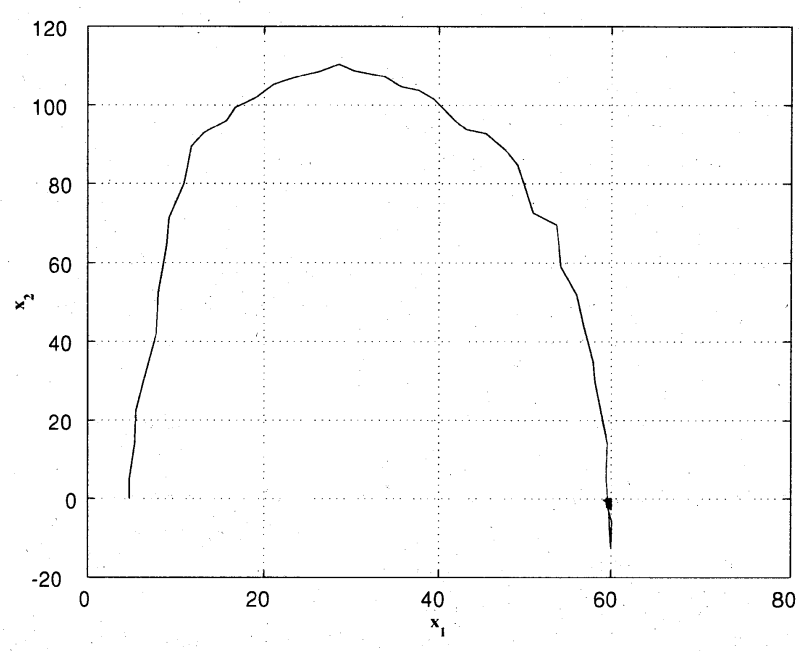

Fig. 13 Experimental phase portrait with sat-function

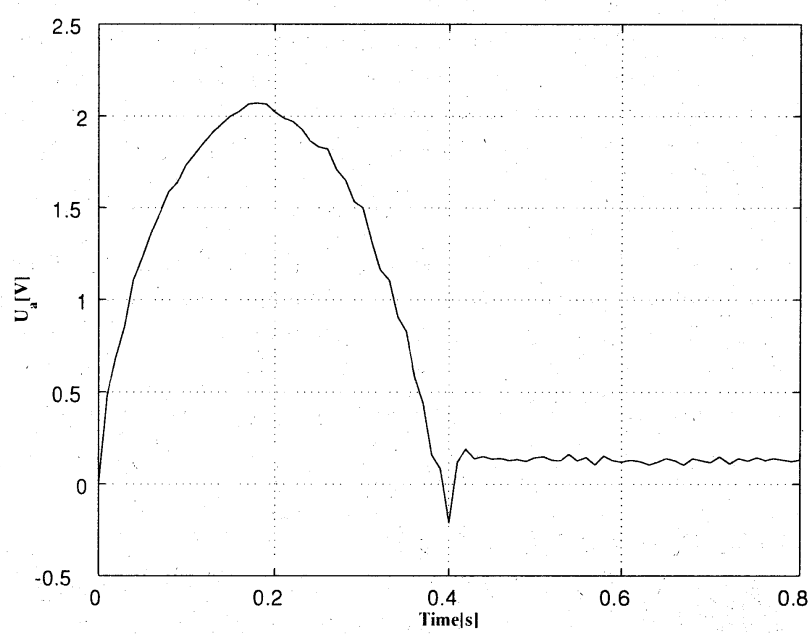

Fig. 14 Experimental control input with sat-function

効性を確認した。

今後の理論的課題としては，ここでは言及しえなかった非 線形VSS オブザーバ併合系としての安定性の証明があげら れる。また実際のスロットルチャンバシステムでは,リター ンスプリングのばね定数 $K_{s}$ はスロットル角度 $\theta$ の非線形 関数になっている。このほかに，バタフライ弁に対する負圧 の影響, ギヤのバックラッシュなどの要素を含めたより高精 度なモデリングが必要である。今後はこのようなモデリング とそれに基づいた制御系設計を行ない，それを実験的にも検 証し, 提案法の実用性をより確かなものにしていきたい.

$$
\text { 参 考 文 献 }
$$

1) 原田 宏 (編)：自動車の制御技術，1/49, 朝倉書店 (1997)

2) C. Rossi, A. Tilli and A. Tonielli: Robust Control of a Throttle Body for Drive by Wire Opening of Automotive Engines, IEEE Trans. Control System Tech., 8-6, 993/1002 (2000)

3) M. Sommerville, C. Hatipoglu and Ümit Özgüner: Switching Control of a Pneumatic Throttle Actuator, IEEE Control System Magazine, 20, 81/87 (1998)

4) S. Umerujan, K-B. Park, T. Hanamoto and T. Tsuji: Fric- 
tionless Control of Robot Arm with Sliding Mode Observer, Proc. of IEEE International Vehicle Electronics Conference, 61/65 (2001)

5) S. Umerujan, T. Hanamoto, T. Tsuji and N. Umeda: Identification and Control of Non-linear System with Friction, Proc. of 6th IEEE International Workshop on Variable Structure Systems, 357/382 (2000)

6）ウメルジャン，ハイレット，中野：電子制御スロットルシステ ムの同定とロバスト制御, 計測自動制御学会論文集, 39-12, 1150/1155 (2003)

7) R. Conatser, J. Wagner, S. Ganta and I. Walker: Diagnosis of Automotive Electronic Control Systems, Control Engineering Practice, 8-6, 1/8 (2002)

8) S. B. Choi and J. K. Hedrick: Robust Throttle Control of Automotive Engines: Theory and Experiment, Trans. of ASME Journal of Dynamic Systems, Measurement and Control, 118, 992/988 (1996)

9) K. D. Young, V. I. Utkin and Ümit Özgüner: A Control Engineer's Guide to Sliding Mode Control, IEEE Trans. Control System Tech., 7-3, 328/342 (1999)

10) S. Umerujan, N. Umeda, T. Hanamoto and T. Tsuji: Model Reference Sliding Mode Control of Flexible Arm with Non-linear VSS Observer, Proc. of 3rd Asian Control Conference, 2893/2898 (2000)

11) V. I. Utkin: Variable Structure Systems with Sliding Mode, IEEE Trans. Automat. Contr., 22-2, 212/222 (1977)

12) R. A. DeCarlo, S. H. Zak and G. P. Matthews: Variable Structure Control of Nonlinear Multivariable System, A Tutorial, Proc. IEEE, 76-3, 212/232 (1988)

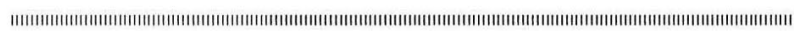

$$
\text { [著 者紹 介] }
$$

\section{Umerujan SAwut（正会員）}

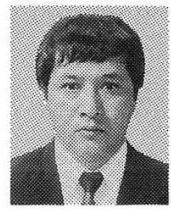

2001 年九州工業大学大学院工学研究科電気工 学専攻博士後期課程修了. 同年 (株) ニッキ入社, 現在に至る。主として，非線形采のロバスト制御 とその応用，システム同定，柔軟構造物の制振制 御，エンジン制御，パワーエレクトロニクスに関 する研究に従事 (博士 (工学)). 電気学会会員.

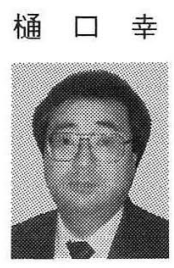

\section{治（正会員）}

1980 年北海道大学大学院工学研究利・電気工学 専攻博士課程単位修得退学. 電気通信大学助手, 講師を経て, 現在同大学助教授. システム制御と その応用（特に，パワーエレクトロニクス）に関 する研究に従事. (工学博士). 電子情報通信学会, 電気学会, IEEE などの会員.

\section{中 野 和 司（正会員）}

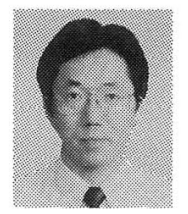

1980 年九州大学大学院工学研究科電気工学専 攻博士課程単位修得退学. 九州大学助手, 福岡工 業大学助教授, 教授在経て, 99 年上り電気通信大 学教授. システム同定・制御に関する研究に従事 (工学博士). システム制御情報学会, 電子情報通 信学会, 電気学会, IEEEなどの会員.

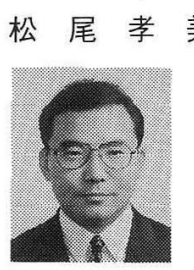

(正会員)

1985 年九州大学大学院総合理工学研究科工ネル ギー変換工学専攻博士後期課程修了. 大分大学助 手，助教授を経て，2004 年より同大学教授. 制御 理論とその応用に関する研究に徥事 (工学博士). システム制御情報学会, 電気学会, IEEE などの 会員.

แ. 